\title{
PENGARUH ANTUSIAS DAN KEKREATIFAN TERHADAP PENINGKATAN HASIL KERJA PADA TELEMARKETING PT GERAHADIKA
}

Oleh :

Fahmi Susanti

Fakultas Ekonomi Program Studi Manajemen

E-mail: dosen02024@unpam.ac.id

\begin{abstract}
ABSTRAK
Hasil akhir yang diinginkan agar menemukan pengaruh antusias serta Kekreatifan terhadap peningkatan hasil kerja Pada Telemarketing PT Gerahadika, dengan cara parsial atau simultan. Dalam penyusunan penelitian memakai methode deskriptip kuantitatif.

Dengan responden sebanyak 56 serta sampel sebanyak 56 petugas, cara pengambilan sampel, secara sampel yang jenuh setiap respondenn mendapat kesamaan dalam peluang. Dianalisis dengan metode regresi linier ganda. Hasil uji hipostesis antusias serta kekreatifan, secara parsial nilai $t_{\text {hitung }}$ masing-masing sebesar 3,025 dan 4,18 dimana semua nilai $t_{\text {hitung }}>t_{\text {tabel. }} . t$ tabel 2,007 Untuk pengaruh simultan diperoleh $\mathrm{F}_{\text {hitung }}>\mathrm{F}_{\text {tabel }}$ yaitu $5.087>3,18 .{ }^{\alpha}=0,05$ taraf signifikan.

Kesimpulan yang diperoleh dengan parsial maupun simultan antusias serta kekreatifan mempunyai pengaruh yang sangat berarti dengan peningkatan hasil kerja. Dengan persamaan regresi linier $Y=-0,07 \mathrm{P}+0,735 \mathrm{X}_{1}+0,928 \mathrm{X}_{2}$ artinya antusias dan kekreatifan memiiki kemampuan untuk mempengaruhi peningkatan hasil kerjanya. Nilai koefisien determinasi 0,157atau sebesar $15,7 \%$ menjelaskan bahwa antusias dan kekreatifan berkemampuan untuk mempengaruhi peningkatan hasil kerjanya sebeesar $15,7 \%$ serta kemampuan variabel yang bebas dimana dalam penelitian ini tidak dilakukan penelitian yaitu $84,3 \%$.
\end{abstract}

Kata Kunci : antusias, kekreatifan, hasil kerja

\section{ABSTRACT}

The purpose of the reseacrh was expected to find the effect of enthusiastiic , frusstration to employee's performance at the pt.Gerahadika, either simultaneously or partially. The method used in the preparation of research was quantitative descriptive. The analytical method used was multiple linear regression analysis with a population of 56 and a sample of 56 employees, the research used non proability sampling method as sampling method. The result of hypothesis test for enthusiastic variable and frustration, partially had value of thitung by value 3 .025, and 4.18 each which means that all value of $t_{\text {hitung }} t_{\text {table. For the result of hypothesis test }}$ simultaneously was obtained $F_{\text {hitung }}>F_{\text {table }}$ by value $5.087^{>}$3.18. With level of significance ${ }^{\alpha}=$ 0.05. It could be concluded that enthusiastic variable and frustratiion partially either simultaneously did has significant influence to employee s performance. With linear regression formula $Y=-0.071+0.735 X_{1}+0.928 X_{2}$ It means enthusiastilic and frusstration had influence power to employee's performance. Coefficient of determination by value $0.157 \%$ or $15.7 \%$. It means that the enthusiastic , frusstration had influence power to employee's performance by value $15.7 \%$ and for the remaining by value $84.3 \%$ is another influence from other freevariables which's not included to this reseach.

Keywords: Workshop, Communication, Employee Performance

PENDAHULUAN.

A. Latar Belakang 


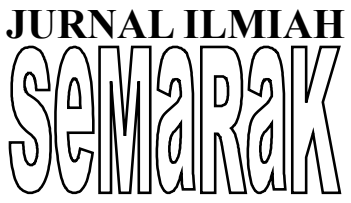

Kepegawaian yaitu Hal terpuncak di suatu badan. Kualitas manusia, yang menentukan hasil kerja badan bisnis. Semakin tingginya kualitas petugas diharapkan semakin tinggi eksis badan usaha pebisnisan. Penguraian. "Niti Semito (1992)" antusias bisa dimaknakan tidak mempunyai kepesimisan dalam menjalani usaha munculnya kesukaran pekerjaannya ada dorongan yang tinggi memacu menyelesaikan tugasnya."

"Hasibuan (1999)" Usaha pebisnisan tidaklah mengandalkan orang-orang yang cerdass sigap tanggap bahkan yang menjadi keutamaan yaitu kerelaan giat bekerjanya serta bersaama-sama memiiki goal ahir akan hasil pekerjaan yang paling baik. Didasari antusias serta kekreatifan "Utami Munandar (1992:47)" tanda-tanda atau gejala buruk ini segera dihindari yaitu goal kerjanya turun, anggota petugasnya sering berganti-ganti, banyak atau sering terjadi kerusakan serta penyepelean.

\section{B. Perumusan Masalah}

1. Besaran pengaruh antara antusias dengan kenaikan hasil kerjanya ?

2. Besaran pengaruh antara kekreatifan dengan kenaikan hasil kerjanya ?

3. Besaran pengaruhnya antara antusias serta kekreatifan dengan cara (bersamasama) dengan kenaikan hasil kerjnya ?

\section{Pembatasan Masalah}

1. Disini dilakukan pemfokusan diantaranya yaitu yang akan dibahas: antusias, kekreatifan, kenaikan hasil kerjanya Telemarketing pt Gerahadika.

\section{D.Tujuan Penelitian.}

Harapannya dapat menjawab hal-hal terkait yaitu:

1. Diketahui pengaruh antara antusias dengan kenaikan hasil kerjanya .

2. Diketahui pengaruh antara kekreatifan dengan kenaikan hasil kerjanya .

3. Diketahui pengaruh antara kekreatifan, serta antusias secara bersama dengan kenaikan hasil kerjanya

\section{TINJAUAN PUSTAKA}

A. Manejemen

Kalau dilihat dari proses tercapainya keputusan sampai tercapainya hasil pekerjaan badan usaha, tekhnik pengelolaan lah yang mempunyai andil sangat penting. Pengelolaan lebih fokus pada cara pengarahan dalam berbagai perencanaan sampai tingkat kontrol (evaluasi) hasil kerjaan dengan muara ahir tercipta keeksisan serta makmurnya badan usaha" pebisnis. Penguraian "Kartonegoro, (2011:3) MIsi dari suatu "pengelolaan" menajemen harus menjadi prioritas yang dilakukan sebelum berjalannya kegiatan, yang akan menjadi sasaran utama dalam pencapaian kegiatannya. Merunut "SP. Hasibuan (208:50)" konsep Pelaksanaan di dalam "pengelolaan" merupakan terstrukturnya pengetahuan dengan berurutan terdiri dari gaya keterampilan dalam mengkaryakan berbagai sumber daya anggotanya serta sumber daya lainnya dengan maksud dicapainya goal dari kegiatan.

\section{B. Menajemen SDM}

Menjadi sebidang illmu yang lahir serta berkembang guna membantu peemahaman, penekanan, pandangan serta penekanan secara menyeluruh pada pengambilan ahir keputusan. yaitu sebagai masukan dari proses tersusunnya stuktur, anggarran, ketetapan, tersusunnya program. "Malayu Hasibuan S.P (2008)". Beberapa caranya yaitu membagi posisi kerjaan, mengangkat, melatiih , Batasan pekerja dengan pemimpiin unit, aturan waktunya, pengurangan serta memberhentikan, menambah anggotanya, Dimana kebutuhan tatananini disesuaikanlah dengan keadaan pebisnisan.

\section{Antusias}

Penguraian "Niti Semito (1992) "antusias bisa dimaknakan tidak mempunyai kepesimisan dalam menjalani usaha munculnya kesukaran pekerjaannya ada dorongan yang tinggi memacu menyelesaikan tugasnya."

yang menjadi keutamaan yaitu kerelaan giat bekerjanya serta bersaama- 
sama memiiki goal ahir akan hasil pekerjaan yang paling baik. Didasari antusias serta kekreatifan "Utami Munandar (1992:47)" yaitu goal kerjanya turun, anggota petugasnya sering bergantigantian, banyak atau sering terjadi kerusakan serta penyepelean, tanda-tanda atau gejala buruk ini segera dihindari.

\section{C.Kekreatifan}

Penguraian "Munandar (2012:31)" yaitu keterampiilan memunculkan sesuatu baik berujud pikiran, pelayanana akan jasa, serta berbentuk barang-barang. Adaalh kebisaan memanfaatkan kesempatan, kebisaan menyelesaikan masallah. Keberhasilannya ini bisa dipengaruhi oleh suasana dalam pekerjaannya serta bagaimana cara -cara penyampaiannya.

C. Hasil Kerja

Anwar Prabu Mangku Negara (2010:67)" penguraian : Hasil dari pekerjaannya karryawan dapat berupa hasil negatip serta hasil kerja positip ,ini berguna untuk memenuhi muara ahir dari usaha.

\section{E. Kerangka Pemikiran}

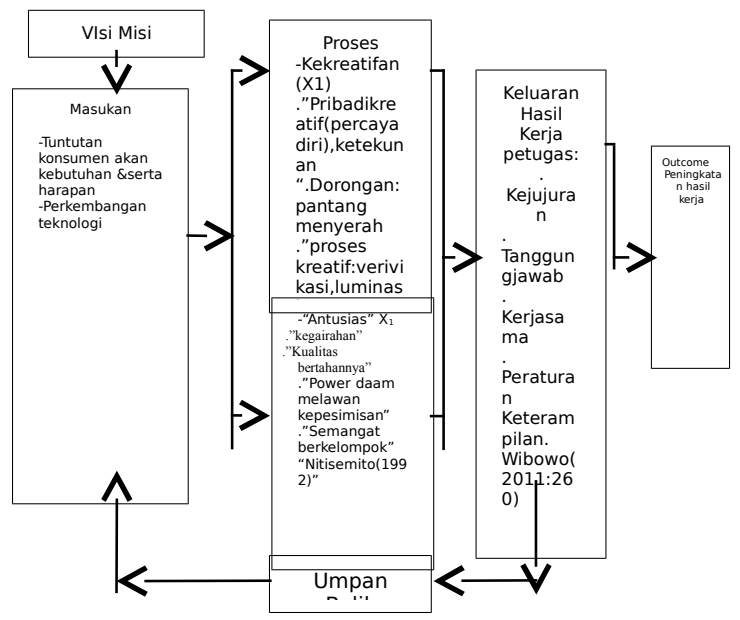

\section{F."Hipotesis Penelitian"}

Kebenaran-kebenaran jawaban sementara ini harus diakukan pengujian kembali. Penguraian "(Riduwan, 2014:35)" Mengacu pada model penelitian diatas, :

1. variabel antusias memiiki pengaruh baik yang sangat berarti kepada hasil kerjanya .
2. variabel kekreatifan memiiki pengaruh baik yang sangat berarti kepada hasil kerjanya.

3. antusias dan kekreatifan memiliki pengaruh baik yang sangat berarti dengan cara simutan kepada hasil kerjanya.

\section{METODE PENELITIAN}

\section{A. Waktu serta Tempat \\ Diilakukan di pt Gerahadyka, berlangsung selama 3 bulan, sejak Desember 2018 selesai Maret 2019.}

\section{B. Metode Penelitian}

Disini mengambil sampel secara langsung dari populasi.Ini adalah ( deskriptip kuantitatif). Dengan harapan dapat diketahui pengaruhnya Antusia, Kekreatifan dengan hasil Kerjanya. "Penguraian Sugiyono (2007:13) penelitian kuantitatif." adalah penelitian yang memiliki goal ahir melakukan uji kemballi hipotesis. Data dikumpulkan dengan alat instrumen, penganalisaan data sifatnya angka (kuantitatif) dipakai dalam meneliti responden beserta sampel

\section{C.Populasi, Sampel}

\section{Populasi}

Merupakan domain bagian suatu objek serta subjek menjadi sesuatu jumlah serta sesuatu karakteristik yang sudah dilakukan penetapan. Penguraian “Sugiyono (2011:57)."Domain Populasi dalam penelitian ini adalah Petugas Telemarketing Tahun 2018 sebanyak 56 orang.

\section{Teknik Dalam Penentuan Data}

Data primer serta data sekunder merupakan sumber dalam Teknik.

\section{Metode Analisis Data}

Adapun Metodenya yaitu :

\section{Uji Validitas.}

Peneliti memakai korelasi Product moment . ini dipakai dalam melakukan pengukuran kesahan koesioner. 


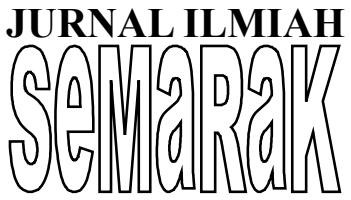

2. Uji Reabilitas

Uji yang berkaitan dengan tingkatan konsiistensi dan stabilitas data atau temuan, "Sugiyono(2011:268)"

\section{Uji Asumsi Klasik}

a. Uji normalitas

Dalam mencaritahu, variabel dependent dan variabel independent mempunyai distribusi data normal atau mendekati.

b. Uji Multikolinieritas

Untuk menguji ada korelasi antara variabel dependent dan variabel independent, VIF < 10.

c. Uji Heterokedastisitas

Dipakai dalam mencaritahu ketidaksamaan varians tiap variabel,

"Sugiyono (2013:124)"

4. Rancangan

Pengujian

Hipotesis

a. Uji t (Parsial)

Dipakai dalam mencaritahu variabel apakah yang mempengaruhi antusias, dan kekreatifan kepada hasil kerja dengan cara (partial)

\section{b. Koefisien Determinasi}

untuk mengetahui \% nilai hasil kerja sebagai variabel terikat

b. Analisis Regresi

1) AnalisisRegresi Sederhana Dipakai dalam mencaritahu berubahnya niai saat dinaik/turunin variabel "Sugiyono 2007"

2) Analisis Regresi Berganda Dipakai dalam mencaritahu adakah pengaruh di kedua variabel , "Gozali (2006)"

\section{d. Uji F (Simultan)}

Dipakai dalam pengujian Untuk menguji antusias, kekreatifan,terhadap hasil kerjanya secara bersama-sama

\section{HASIL DAN PEMBAHASAN}

\section{A. Hasil Uji Instrumen Penelitian 1. Hasil Uji Validitas}

\begin{tabular}{|c|c|c|c|}
\hline $\begin{array}{c}\text { N } \\
\text { o }\end{array}$ & $\begin{array}{c}\text { Nilai r } \\
\text { Hitung }\end{array}$ & $\begin{array}{c}\text { Nilai r } \\
\text { Tabel }\end{array}$ & Sipulan \\
\hline \multicolumn{4}{|c|}{ antusias $\left(\mathrm{X}_{1}\right)$} \\
\hline 1 & 0,600 & 0,266 & Valid \\
\hline 2 & 0,490 & 0,266 & Valid \\
\hline 3 & 0,422 & 0,266 & Valid \\
\hline 4 & 0,602 & 0,266 & Valid \\
\hline 5 & 0,641 & 0,266 & Valid \\
\hline 6 & 0,420 & 0,266 & Valid \\
\hline 7 & 0,652 & 0,266 & Valid \\
\hline 8 & 0,510 & 0,266 & Valid \\
\hline \multicolumn{5}{|c|}{ Kekreatifani $\left(\mathrm{X}_{2}\right)$} \\
\hline 9 & 0,531 & 0,266 & Valid \\
\hline 10 & 0,613 & 0,266 & Valid \\
\hline 11 & 0,269 & 0,266 & Valid \\
\hline 12 & 0,269 & 0,266 & Valid \\
\hline 13 & 0,529 & 0,266 & Valid \\
\hline 14 & 0,630 & 0,266 & Valid \\
\hline 15 & 0,485 & 0,266 & Valid \\
\hline 16 & 0,390 & 0,266 & Valid \\
\hline \multicolumn{5}{|c|}{ Peningkatan hasil Kerja (Y) } \\
\hline 17 & 0,614 & 0,266 & "Valid" \\
\hline 18 & 0,424 & 0,266 & "Valid" \\
\hline 19 & 0,331 & 0,266 & "Valid" \\
\hline 20 & 0,278 & 0,266 & "Valid" \\
\hline 21 & 0,275 & 0,266 & "Valid" \\
\hline 22 & 0,587 & 0,266 & "Valid" \\
\hline 23 & 0,381 & 0,266 & "Valid" \\
\hline 24 & 0,455 & 0,266 & "Valid" \\
\hline \multicolumn{5}{|c|}{} \\
\hline
\end{tabular}

“Sugiyono (2009:172)” Dipakai dalam mencaritahu valid tidaknya tiap variabel ,mengacu pada. $\mathrm{r}_{\text {tabel }}$ product moment,$d f=(\dot{\alpha}, \mathrm{n}-2)$. responden sejumlah 56 petugas akan dihasilkan $\mathrm{r}_{\text {tabel }}=0,266$ signifikansi $<0,05$. Disimpulkan valid dengan mengacu $r_{\text {hitung }}>r_{\text {tabel }}$.

\section{a. Uji Reliabilitas}

Dalam Gozali(2006: 182) Akan disimpulkan reliabel, dengan alasan mempunyai nilai "Cronbach Alpha nya yang melebihi 0,6." Setelah diakukan penghitungan didapatkan hasil niai Conbrachnya melebihi 


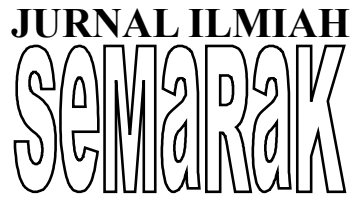

06 yaitu 0,877.Dan didapatkan $r$ tabel 0,266 dan 5\% signifikan. Kesimpulannya Conbrach alpha $>0,60(0,73)$ artinya item-item tersebut bersifat reliable. Semuanya reliabel dengan interpretasi kuat sehingga bisa dijadikan alat pengukur (variabel tersebut ).

\section{Hasil Uji Asumsi Klasik}

a. Hasil Uji Normalitas

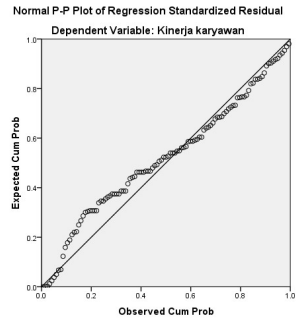

Dapat dilihat dari grafik di atas bahwa penyebaran titik mendekati dan titik terbentuk disekeliling "garis lurus diagonal, "dapat diartikan bahwa regresi" tersebut menghasilkan niai-niai reesidu yang normal. Selanjutnya dalam mencaritahu kenormalan distribusi data( Nilai signifikan melebihi 0,05 ) yang terkait tersebut harus dilakukan dengan pengujian One Sample Kolomogorov Smirnov dipakai untuk mencaritahu residu ini distribusinya dalam keadaan normal ataukah sebaliknya (tidak normal).

One-Sample Kolmogorov-Smirnov Test

\begin{tabular}{|ll|r|}
\hline & \multicolumn{1}{|c|}{$\begin{array}{c}\text { Unstandardize } \\
\text { d Predicted } \\
\text { Value }\end{array}$} \\
\hline $\mathrm{N}$ & Mean & 56 \\
Normal & S. Deviation & .3445800006 \\
Parameter & Absolute & .122 \\
Most Extrem & Absitive & .069 \\
Difference & Positive & -.123 \\
& Negative & .924 \\
Test Statistic[ & .359 \\
Asymp. Sig. (2-tailed)
\end{tabular}

a. Test distribution is Normal.

b. Calculated from data.

c. Lilliefors Significance Correction.

Jika diihat hasil test komogrov tersebut dapat dikatatakan niai residu dalam keadaan normal yaitu nilai signifikansi 0359 (Asymp. Sig 2-tailed) . Dikarenakan signifikan melebihi nilai $0,05(0,359>0,05)$.

\section{b. Hasil Uji Multikolinieritas}

\begin{tabular}{|ll|r|r|}
\hline \multirow{2}{*}{ Model } & \multicolumn{2}{c|}{$\begin{array}{c}\text { Collinearity } \\
\text { Statistics }\end{array}$} \\
\cline { 2 - 4 } & & Tolerance & \multicolumn{1}{c|}{ VIF } \\
\hline 1 & (Constant) & & \\
& Antusias & .806 & 1.239 \\
& Kekreatifan & .806 & 1.239 \\
& & & \\
\hline
\end{tabular}

Dari hasilnya output data didapatkan bahwa gejala -gejala terjadinya korellasi tidak ada dengan mengacu pada VIF nilainya kurang dari sepuluh $(<10)$ serta didapatkan nilai tolleransi melebihi $0,10(>0,10)$. Kesimpuannya tidak adanya korelasi pada masing-masing variable bebasnya.

\section{c. Hasil Uji Heteroskedastisitas}

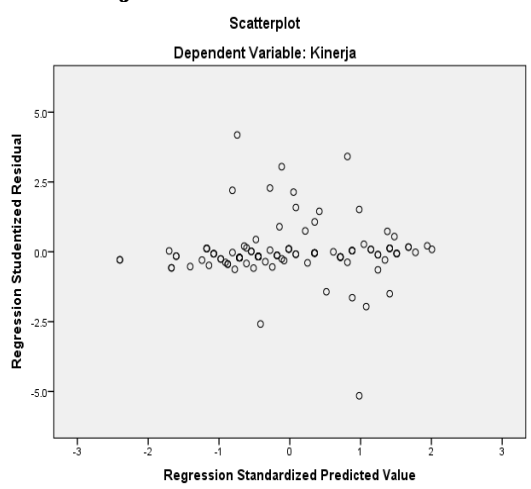

Disimpulkan permasalahan heteroskedastisitas tidak ada didalam regresi ini. titik-titik ini membentuk pola yang tidak jelas, serta titik-titik ini tersebut melakukan penyebaran pada bagian atas dan bagian bawah angka 0 sumbu $\mathrm{Y}$, hal tersebut yang terlihat pada hasil keluaran gambaran .

\section{B. Analisis Verifikatif Hasil Pengaruh Secara Partial}

1. Hasil Uji Hipotesis

Hasil Pengujian Hipotesis Antusias $\left(X_{1}\right)$ terhadap peningkatan Hasil Kerja (Y)

\section{Coefficients}

\begin{tabular}{|l|l|l|}
\hline Model & $\mathrm{T}$ & Sig. \\
\hline
\end{tabular}




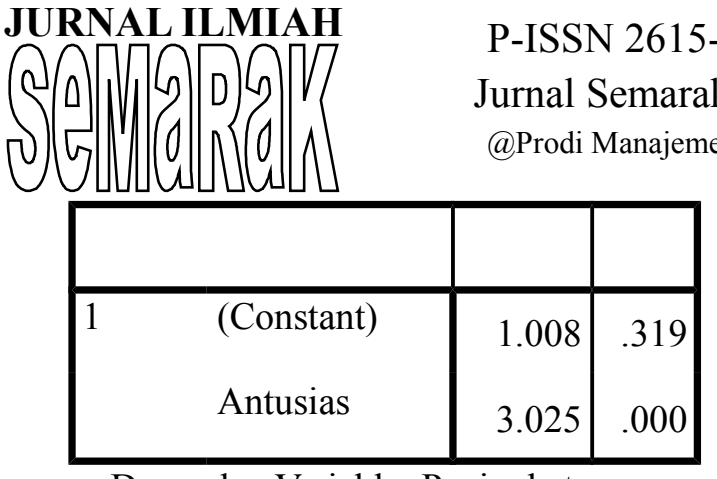

a. Dependen Variable: Peningkatan hasil kerja

Berdasarkan output diperoleh hasil sebagai berikut: Hasil uji parsial menunjukkan variabell Antusis memiiki pengaruh yang baik kepada variabel peningkatan hasil kerja dilihat dari nilai $t_{\text {hitung }}$ untuk variabel antusias $(3.025)>$ nilai $t$ tabel $(2,007)$ dan dihasilkan variabel antusias memiliki pengaruh sangat berarti kepada variabel peningkatan hasil kerja, signifikansi t untuk variabel memiliki kemampuan untuk mempengaruhi peningkatan hasil kerja. Kesimpulan nya adalah antusias mempunyai pengaruh kepada peningkatan hasil kerja.

\section{Hasil Pengujian Hipotesis kekreatifan $\left(\mathrm{X}_{2}\right)$ terhadap peningkatan hasil kerja, $(\mathrm{Y})$}

\begin{tabular}{|c|c|c|c|}
\hline \multicolumn{4}{|c|}{ Coefficients $^{\mathrm{a}}$} \\
\hline \multirow{2}{*}{\multicolumn{4}{|c|}{ Model }} \\
\hline & & & \\
\hline & (Constant) & 1.006 & .317 \\
\hline & Kekreatifan & .418 & .000 \\
\hline
\end{tabular}

a. Dependen Variable: Peningkatan hasil kerja

Berdasarkan output tabel diperoleh hasil sebagai berikut: Hasil uji parsial menunjukkan kekreatifan memiliki pengaruh baik (positif) kepada variabel peningkatan hasil kerja. dilihat dari hasil tersebut $(4,18)$ yaitu nilai thitung untuk variabel kekreatifan yang melebihi besaran $t$ tabel $(2,007)$ dan didapatkan hasil variabel kekreatifan mempengaruhi variable peningkatan hasil kerja signifikansi t untuk variabel kekreatifan yaitu signifikan 0 , batasnya kurang besar dari 0,5 oeh sebab itu Hipotesis 0 ditolak serta Hipotesis a tidak ditolak untuk variabel kekreatifan. Maka dengan itu secara parsial variabel kekreatifan memiliki pengaruh yang sangat berarti dengan peningkatan hasil kerja
Hasil Koefisien Determinasi (R-Square) / $\mathrm{X}_{2}$ terhadap $\mathrm{Y}$.

\begin{tabular}{|l|l|r|r|}
\multicolumn{4}{c}{ Model Summary } \\
\begin{tabular}{|l|l|r|r|}
\hline Model & R & R Square & $\begin{array}{r}\text { Adjusted } \\
\text { R Square }\end{array}$ \\
\hline 1 & .399 & .167 & .148 \\
\hline
\end{tabular}
\end{tabular}

a. Predictors: (Constant), kekreatifan

Berdasarkan output tabel dapat dilihat bahwa nilai $\mathrm{R}$ square 0,167 diubah menjadi persen yaitu $16,7 \%$. Adapun $16,7 \%$ adalah besarannya variabel kekreatifan dalam me mpengaruhi variabel peningkatan hasil kerja. Variabel bebas lainnya yang memberikan pengaruh tetapi tidak diakukan penelitian yaitu $83,3 \%$

\section{Hasil Analisis Regresi / $\mathbf{X}_{2}$ terhadap Y}

\section{Coefficients $^{\mathrm{a}}$}

\begin{tabular}{|ll|r|r|}
\hline \multirow{2}{*}{\multicolumn{2}{|l|}{}} & \multicolumn{2}{|c|}{$\begin{array}{c}\text { Unstandardized } \\
\text { Coefficients }\end{array}$} \\
\cline { 3 - 4 } \multicolumn{2}{|l|}{ Model } & \multicolumn{1}{|c|}{ B } & \multicolumn{1}{|c|}{ Std. Error } \\
\hline 1 & (Constant) & -0.71 & .920 \\
& kekreatifa & .928 & .921 \\
\hline
\end{tabular}

a. Dependen Variable: Peningkatan hasil kerja

Berdasarkan output pada tabel diperoleh hasil persamaan regresi $\hat{Y}=-0.071+0.0928$ $\mathrm{X}_{2}$, Penjelasannya adalah : Konstanta sebesar -0.071 menyatakan bahwa tanpa variabel kekreatifan, peningkatan hasil kerja, mempunyai nilai yaitu sebesar -0.071 . Nilai coefficents yaitu 0.0928 . yang berarti andaikan kekreatifan meningkat sebesar 1 satuan akan berdampak peningkatan sebanyak 0,0928. Pada persamaan tersebut dapat dilihat bahwa kekreatifan memiliki kemampuan mempengaruhi "peningkatan hasil kerja. Kesimpulannya adalah kekreatifan berpengaruh kepada peningkatan hasil kerja.

4. Hasil Pengujian Pengaruh antusias, kekreatifan terhadap "peningkatan hasil kerja"

ANOVA $^{\mathrm{a}}$ 


\begin{tabular}{l} 
JURNAL ILMIAH \\
\multicolumn{3}{c|}{$\begin{array}{c}\text { P-ISSN 2615- } \\
\text { Jurnal Semarak } \\
\text { Model }\end{array}$} \\
\begin{tabular}{|l|c|c|c|}
\hline 1 & Regression & 5.087 & $.000^{\mathrm{b}}$ \\
& Residual & & \\
& & \\
& & & \\
\hline
\end{tabular}
\end{tabular}

a. Dependen Variable: Peningkatan hasil kerja

b. Predictors: (Constant antusias,kekreatifan

Berdasarkan output tabel nilai (5.087) yaitu $\mathrm{F}$ hitung melebihi besaran dari nilai $\mathrm{F}_{\text {tabel }}(3,18)$ adapun signifikan. $\alpha(0,000)$ yang tidak melebihi alpha $5 \% \quad(0,05)$. Kesimpulannya didapatkan bahwa Hipotesis 0 tidak diterima serta Hipotesis a tidak ditolak.. maka dengan cara simultan antusias, kekreatifan memiliki pengaruh yang sangat berarti kepada peningkatan hasil kerja.

Hasil Koefisien Determinasi Square) / $\mathbf{X}_{1}, \mathbf{X}_{2}, \mathbf{X}_{3}$ terhadap $\mathbf{Y}$

\begin{tabular}{|l|c|r|r|}
\hline Model & $\mathrm{R}$ & R Square & $\begin{array}{r}\text { Adjusted } \\
\text { R Square }\end{array}$ \\
\hline 1 & $.397^{\mathrm{a}}$ & .157 & .142 \\
\hline
\end{tabular}

a. Predictors: (Constant antusias, kekreatifan

b. Dependen Variable: Peningkatan hasil kerja

Hasil output yaitu R Square 0,157 dan diubah menjadi persen yaitu $15,7 \%$. Artinya bahwa persentase pengaruh antusias,dan kekreatifan terhadap peningkatan hasil kerja besarannya $15,7 \%$, variabell bebas lainnya besarnnya yaitu $84,3 \%$ tetapi tidak dilakukan penelitian .

\section{Hasil Analisis Regresi / $X_{1}, X_{2}$, terhadap $Y$}

\section{Coefficients $^{\mathrm{a}}$}

\begin{tabular}{|l|r|r|}
\hline \multirow{2}{*}{ Model } & \multicolumn{2}{|c|}{$\begin{array}{c}\text { Unstandardized } \\
\text { Coefficients }\end{array}$} \\
\cline { 2 - 3 } & \multicolumn{1}{|c|}{$\mathrm{B}$} & \multicolumn{1}{c|}{$\begin{array}{c}\text { Std. } \\
\text { Error }\end{array}$} \\
\hline 1 (Constant) & -.071 & .170 \\
& .735 & .242 \\
Antusias & .928 & .921 \\
Kekreatifan & .928 & \\
\hline
\end{tabular}

a. Dependen Variable: Peningkatan hasil Kerja

Berdasarkan output hasil persamaan regresi : $\hat{\mathrm{Y}}=-0.071+0,735 \mathrm{X}_{1}+0,928 \mathrm{X}_{2}$. artinya antusias serta kekreatifan memiliki pengaruh kepada peningkatan hasil kerja. Angkakonstanta 0.071 menyatakan bahwa tanpa variabel antusias dan kekreatifan $\mathrm{Y}$ nilai besarannya 0.071 nilai coefisien 0,0735 yang berarti andaikan antusis meningkat sebesar satu-satuan dan variabel antusisme tetap, akan berdampak peningkatan pada peningkatan hasil kerja, sebanyak 0,0735 .Dengan bertambahnya 1 satuan pada variabel kekreatifan serta variabel antusias tetap akan berdampak 0,0928 pada peningkatan hasil kerja". Kesimpulannya antusias serta kekreatifan meimiliki pengaruh kepada peningkatan hasil kerja.

\section{Pembahasan}

Merujuk pada hasil yang diperoleh dari deskripsi penganalisaan dilakukanlah pembahasan berdasar frekuensi pemilihan opsi pada setiap pernyataan pada variabel independen dan dependen (variabel antusias), kekreatifan dan peningkatan hasil kerja) yang diajukan kepada responden penelitian sebagai berikut:

\section{Variabel antusias $\left(X_{1}\right)$}

Hasil Hipotesis disimpulkan antusis mempunyai pengaruh yang sangat berarti kepada peningkatan hasil kerja. Pembahasan pada penelitian ini memperkuat pendapat beberapa peneliti yang lain. Beberapa diantaranya yaitu Ananti,wahyu(2017), yang bisa disimpulkan bahwa antusias memiliki pengaruh baik yang sangat berarti kepada peningkatan hasil kerja .

\section{Variabel Kekreatifan $\left(\mathbf{X}_{2}\right)$}

Kesimpulan yang bisa didapat dari Hipotesis yaitu antusis memiliki pengaruh sangat berarti kepada peningkatan hasil kerja. Pembahasan pada penelitian ini bisa memperkuat pendapat beberapa peneliti yang lainnya. Beberapa diantaranya yaitu Ananti,wahyu ajeng (2017), dimana bisa disimpulkan yaitu antusis memiliki pengaruh baik yang sangat berarti kepada peningkatan hasil kerja .

\section{Variabel antusias $\left(\mathrm{X}_{1}\right) \mathrm{dan}$}




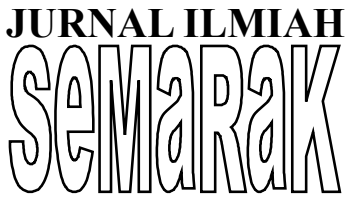

kekreatifan(x2)

Hasil Hipotesis diperoleh kesimpulan bahwa antusias dan kekreatifan memiliki pengaruh yang sangat berarti kepada peningkatan hasil kerja. Di pembahasan ini yang bisa disimpulkan yaitu antusiasm,dan kekreatifan bersama-sama memiliki pengaruh baik yang sangat berarti kepada peningkatan hasil kerja.

\section{KESIMPULAN DAN SARAN}

\section{A. Kesimpulan}

Antusias mempunyai pengaruh yang sangat berarti kepada peningkatan hasil kerja. Besaran berpengaruhnya dari yaitu $73.5 \%$. antusias serta besaran yang mempengaruhi di varriabel bebas yang lainnya yang tidak dilakukan penelitian yaitu $1.8 \%$. Persamaan regresi linier $\hat{Y}=-0.071+0.0735 \mathrm{X}_{1}$.

Kekretifan mempunyai pengaruh yang sangat berarti kepada "peningkatan hasil kerja. Besaran berpengaruhnya dari kekreatifan yaitu 92,8\%. Serta besaran yang mempengaruhi varriabel bebas yang lainnya yang tidak dilakukan penelitian yaitu $7.2 \%$. Persamaan regresi linier $\hat{Y}=$ $-0.0721+0.0928 \mathrm{X}_{2}$.

antusiasm dan kekreatifan secara bersama -sama memiliki pengaruh yang sangat berarti kepada peningkatan hasil kerja. Besaran pengaruhnya dari antusiasm serta kekreatifan yaitu $15,7 \%$. Serta besaran yang mempengaruhi berasal dari varriabel bebas yang lainnya yang tidak dilakukan penelitian yaitu $84,3 . \%$. Persamaan regesi linier $\hat{Y}=$ $-0.071+0,0735 \mathrm{X}_{1}+0,928 \mathrm{X}_{2}$

\section{B. Saran}

Bagi pt Gerahadika merujuk pada jawaban yang diperoleh di koesioner daam ketiga variabell didapatkan temuan sebagai berikut:

1. Antusias

9 responden (18\%) menyatakan raguragu di sub indikator ketersediaan fasilitas penunjang serta program pelatihan, disarankan kepada pimpinannya pt Gerahadika harus menyiapkan kelengkapan fasilitas fisikk, pengembanga petugas harus dilaksanakan berkelanjutan guna meningkatkan komit serta kompetensii sehingga tercapainya kiat bisnis.

2. Kekreatifan

9 respondenn (18\%) menyatakan ragu-ragu di sub indikator episiensi kekreatifan

Disarankan pimpinan pt gerahadika lebih meningkatkan ruang kesempatan untuk petugas menuangkan gagassan karya baru berinovasi ,sehingga suasana ruang kerja nyaman, koordinasinya di lingkungan ruang kerja terjalin dengan baik

3. peningkatan hasil kerja,

9 responden (18\%) menyatakan ragu

- ragu di sub indikator jasa, di sarankan kepada pimpinan pt Gerahadika harus mendorong petugas dalam kekreatifannya dengan memberikan penghargaan ,serta tambahan jasa pada yang berprestasi.

\section{DAFTAR PUSTAKA}

Anwar Prabu Mangkunegara,2006, Manajemen SDM Dalam Organisasi Publik dan Bisnis, Rosdakarya,Bandung , 2010, Manajemen Sumber Daya Manusia perusahaan, Remaja Rosdakrya,Bandung.

Arikunto, Suharsismi., 2011, Prosedur Suatu Penelitian; Pendekatan Praktek, Edisi Revisi V, Rineka Cipta, Jakarta.

Ghozali, Imam,2011, Aplikasi Analisis Multivariate dengan program SPSS, Universitas Diponegoro, Semarang.

Kertonegoro, 2011,Prinsip dan Teknik Manajemen, Bandung

Mangkuprawira, 2004, Manajemen Sumber Daya Manusia, Galia Indonesia, Jakarta

Nawawi, Hadari, 2003, manajemen Strategik Organisasi,Non Profit Bidang Pemerintahan, Gajah Mada 


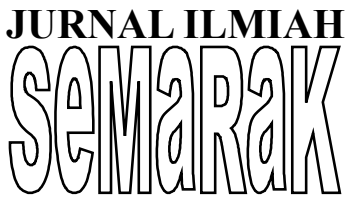

Unyversity Press, Yogyakarta

Nitisemito. Alex S,1992, manajemen Personalia, Ghalia, Cetakan delapan, Jakarta

Utami munandar,1992, mengembangkan Bakatdan Kreatifitas Anak Sekolah,PT Gramedia Widiasarana, Jakarta

Ray dalam Sofyandi, 2008, Manajemen Sumber Daya Manusia, Graha Ilmu.Yogyakarta

Ridwan Sani,2014,, Pembelajaran Saintifik untuk Implementasi Kurikulum 2013 Bumi Aksara, Jakarta

Sugiyono, 2007, Sattistika Untuk Penelitian, CV Alfabetha, Bandung ------, 2009, Metode Penelitian Kuantitatif,Kualitatif danR\&D, Alfabetha, Bandung

$\begin{array}{cc}\text { 2011,Metode } & \text { Penelitian } \\ \text { Kuantitatif,Kualitatif } & \text { danR\&D, } \\ \text { Alfabetha, Bandung } & \end{array}$

2013,metodologi Penelitian Kuantitatif Kualitatif Dan R\&D , Alfabeta, Bandung

SP Hasibuan, 2008, Manajemen Dasar, Graha Ilmu, Yogyakarta

1999, Organisasi dan motivasi Dasar Peningkatan Produktivitas, Bumi Aksara, Jakarta

\section{JURNAL}

Ananti wahyu ajeng Pratiwi, 2017, Pengaruh Budaya Organisasi dan Semangat Kerja, Fakultas Psikologi UMP

Pengaruh Gaya Kepemimpinạn Bụdaya Organisasi dan Inovasi Pemimpin Terhadap Kinerja Karyawan Daihatsu Kharisma Jurnal Emba Vol.6 No.1 Januari 2018

Didit Daramwan,Variabel Seamngat kerja dan Indikator Pengukurannya, Sta Pengajar STIE ahardika Surabaya
Idtesis.com.Indikatorsemangatkerja eprints.uny.ac.id repository.up.ac.id 